\title{
Environmental Consequences of Rapid Urbanisation: Bamenda City, Cameroon
}

\author{
Emmanuel M. Nyambod \\ Department of Human Ecology, Vrije Universiteit Brussels, Brussels, Belgium. \\ Email: enyambod@yahoo.co.uk
}

Received December 21 $1^{\text {st }}$,2009; revised February $27^{\text {th }}$, 2010; accepted February $28^{\text {th }}, 2010$.

\begin{abstract}
Human settlement conditions in many parts of the world, particularly the developing countries, are deteriorating. Natural hazards now occur right at our door steps and the frequency of occurrence and magnitude of damages that they cause is seen to be on an increase especially in poor urban communities. The natural environment is deteriorating at a rate faster than the rate at which natural occurring processes and resources available within the environment can replenish. If left unabated, landslides, flooding, sporadic fire outbreaks, collapse of major road axis, houses and bridges have the potential of plunging urban centre's into an abyss of environmental chaos. This paper chooses Bamenda cityCameroon, a rapidly expanding city in the third world as an example. The paper therefore assesses the overall situation of deteriorating urban quality by randomly selecting some of the quarters within Bamenda city that are generally considered as hazard prone. It was noticed that deteriorating urban quality stems from the phenomenon of rural exodus. The situation is further exacerbated by inappropriate systems of land administration, poverty and an overall anarchy and ignorance in the handling of environmental issues. This paper therefore calls for a multidisciplinary and holistic range of approaches to solving present day environmental hazards of Bamenda. It calls for the adoption of modern technology and the systematization of the processes of land acquisition and registration especially at state and local government levels.
\end{abstract}

Keywords: Bamenda City, Hazards, Environment, Flooding, Landslide

\section{Introduction}

The word "urbanization" refers to an increase in the proportion of national or regional population living in cities [1]. For the first six thousand years of urban life, no society was long able to maintain an urban percentage greater than from 5 to 10 percent. Starting in late eighteenthcentury England, however, one nation after another experienced an accelerating shift from rural to urban population. After several generations of rapid urbanization, the process leveled off toward a new equilibrium in which about three-quarters of the population lived in cities and many of the rest pursued city-related activities in smaller towns.

Chapter 7 of Agenda 21 acknowledges the fact that human settlement conditions in many parts of the world, particularly the developing countries, are deteriorating mainly as a result of the low levels of investment in the sector attributable to the overall resource constraints in these countries. The natural environment of Bamenda is deteriorating at a rate faster than the rate at which natural occurring processes and resources available within the environment can replenish.
Emerging as a city in the colonial days of the British, French and Germans from around $19^{\text {th }}$ century, Bamenda has transcended from being a traditional monoculture village to becoming a complex heterogeneous city offering many services to its inhabitants as well as to its hinterland. Besides hosting the headquarters of the North West region and thereby serving as the socioeconomic nerve wire of the region, it serves as a pivot to major political, religious and cultural happenings in Cameroon. Bamenda is located at a cross route linking cities in neighboring Nigeria such as Enugu and Calabar to the economic and capital cities of Douala and Yaounde respectively.

The numerous services offered in Bamenda have somehow encouraged rural exodus and accelerated the urbanization process of Bamenda. People; especially the youthful folk migrate into Bamenda in search of jobs and scholarly pursue. This net flow of population within the recent past has not been compensated for by an increase of or improvement in social infrastructure. The demand for low cost housing and social amenities such as roads, waste disposal sites, water as well as landed property has noticed an exponential increase since the 1980s. Varied 
forms of housing developments that are dependent on miniature, inaccessible and undulating footpaths have led to a situation of urban sprawl and an overall deterioration in the scenic beauty of Bamenda city. The devaluation of the CFA currency by $50 \%$ in the 1990 s, increase in the price of building materials and a general increase in cost of a square foot of land have led to a situation of uncontrolled and illegal occupancy and an overall disorderliness in civil life as people are now seen to occupy high risk hill slope systems and swampy valleys more than ever before.

The gradual but steady encroachment of population onto high risk soon is characterized by the erection of unplanned buildings (no building permits) of very low quality standards. Such lands are known to be about 300 times cheaper than properly located pieces of land within the city. The acquisition of such land is usually through mere land agreement and not through the complicated, expensive, bureaucratic and time consuming land title acquisition procedure whose cost could well be more than a hundred times higher than the value of land in such unstable zones. As a consequence to the above, the city of Bamenda is witnessing an ever increasing high in the number of natural hazards, which very often claim lives; a situation which if left unabated could plunge the city into an abyss of widening urban instability and decay.

The situation of urban hazard within this millennium appears to be different in scope and magnitude. Not only do such hazards occur frequently, but they are seen to occur with even greater intensity and at threatening scales seen to be dangerous to the very existence of man and to the disruption of a onetime ecologically balanced complex. The situation within the city of Bamenda is that which beck for an answer as the incidence of flash flooding, mudflow, landslides, fire disasters, and sheet and gulley erosion are on a disheartening increase in the phase of a rapidly expanding human numbers. Ensuing natural hazards that occur due to man's disruption of the geomorphic processes are that which man himself can't prevent from occurring. They are certainly inevitable and man has a price to pay.

The one time physical environment of Bamenda that knew little or no stress in the 60's has seen the progressive replacement of pre-existing vegetation with buildings and pavements of varying degree and quality. In as much as this change is seen as man's quest to improve on his immediate environment with the desire to lead a more comfortable life, there is need for such change to follow a planned and comprehensive pattern that can still stand the taste of time in generations to come. This paper calls for the adoption of a multidisciplinary approach in the planning of present day Bamenda. Bamenda, the metropolitan centre of the North West Region has a panoramic and well-drained natural site. In spite of the existing largely unplanned urban development, it could be replanned, upgraded and systematically extended to offer a beautiful, healthy, safe, secured, comfortable, convenient and functional living environment which provides equitable opportunities to all its inhabitants. To do this, the current situation where private interest over land completely dominates public interest has to be reversed without necessarily undermining the former.

\section{Objectives and Hypothesis of the Study}

The aim of this study is to point out the peculiarities about urban catastrophe in Bamenda. The main objectives that this research aimed to achieve were the following:

- To show the extent to which haphazard urban development planning provokes and is prone to the occurrence and effects of urban environmental hazards.

- To make an assessment of peoples perception of urban environmental hazards in Bamenda

- To propose appropriate ways in which urban environmental hazards in Bamenda could be checked.

\section{Hypothesis}

Rapid urbanization does not lead to urban environmental problems

\section{Statement of the Problem}

Bamenda city has seen the progressive deterioration in its environmental quality as a result of rapid and unplanned urbanization that took off since the early 80's. There has thus been an upwards surge in the frequency of occurrence of natural hazards within the environment which if left unabated have the potential of plunging Bamenda into an abyss of environmental chaos. Landslides, flooding, sporadic fire outbreaks, collapse of major road axis, houses and bridges are thus on an ever increasing high.

There is thus a rising need for concrete environmental management plans that can meet the taste of time in the short, medium and long term for present day Bamenda. At the same time the environmental implications of urban development should be recognized and addressed in an integrated fashion by all countries, with high priority being given to the needs of the urban and rural poor, the unemployed and the growing number of people without any source of income [2].

\section{Conceptual Framework}

In the developing world most especially, high birth rate within the surrounding hinterland and within an urban sector leads to deterioration in living condition and pressure on rural resources. In a quest to find a way out of this dilemma people often migrate to the cities where they hope to better their living conditions. This more 
often than not leads to overcrowding and the development of shanks and squatters within the urban built with attendant deterioration in urban environmental quality. Figure 1 below shows the intricate link between rising urban population and urban environmental quality problems.

\section{Methodology}

\subsection{Primary Data}

Questionnaires, historical linings, interview, visual appreciation through pictures were used to collect raw data from the field. The city of Bamenda was classified into highly prone, moderately prone and least prone quarters with respect to the occurrence of natural hazards following some critical satellite interpretation exercise. Flood prone areas were digitized using Arc View GIS 3.2. For the purpose of sustainable management of the built environment, the researcher saw the need to concentrate more on four quarters classified as highly prone- Abangoh, Sisia, New layout Nkwen, Ngohmgham and Mulang. These quarters were further broken down into two categories. Category one quarters relate to quarters that have been earmarked for demolition and rehabilitation by the state. These include part of Abangoh, Sisia and New layout Nkwen. These quarters have sudden and localized hazards whose occurrence more often than not provokes the attention of public authority. Category two quarters refers to quarters whose hazards though recurrent appear to vary in nature and are delocalised (Ngohmgham and Mulang). Digitised data of habitat swamps and contour lines were superimposed using geo-informatics layering concept to further concretize this categorization.

Twenty questionnaires were administered to each of the quarters that make up the respective categories. The questionnaires comprised of short structured questions to which respondents were asked to make a choice between "Yes" or "No". Respondents equally had to provide short answers in some cases for clarification. The responses that ensued were then coded and introduced into statistical packages such as excel and SPSS. In this way some results were obtained, presented in the form of graph; reflecting the actual situation on the ground. From this some recommendations that to lead to an amelioration of the existing situation were given.

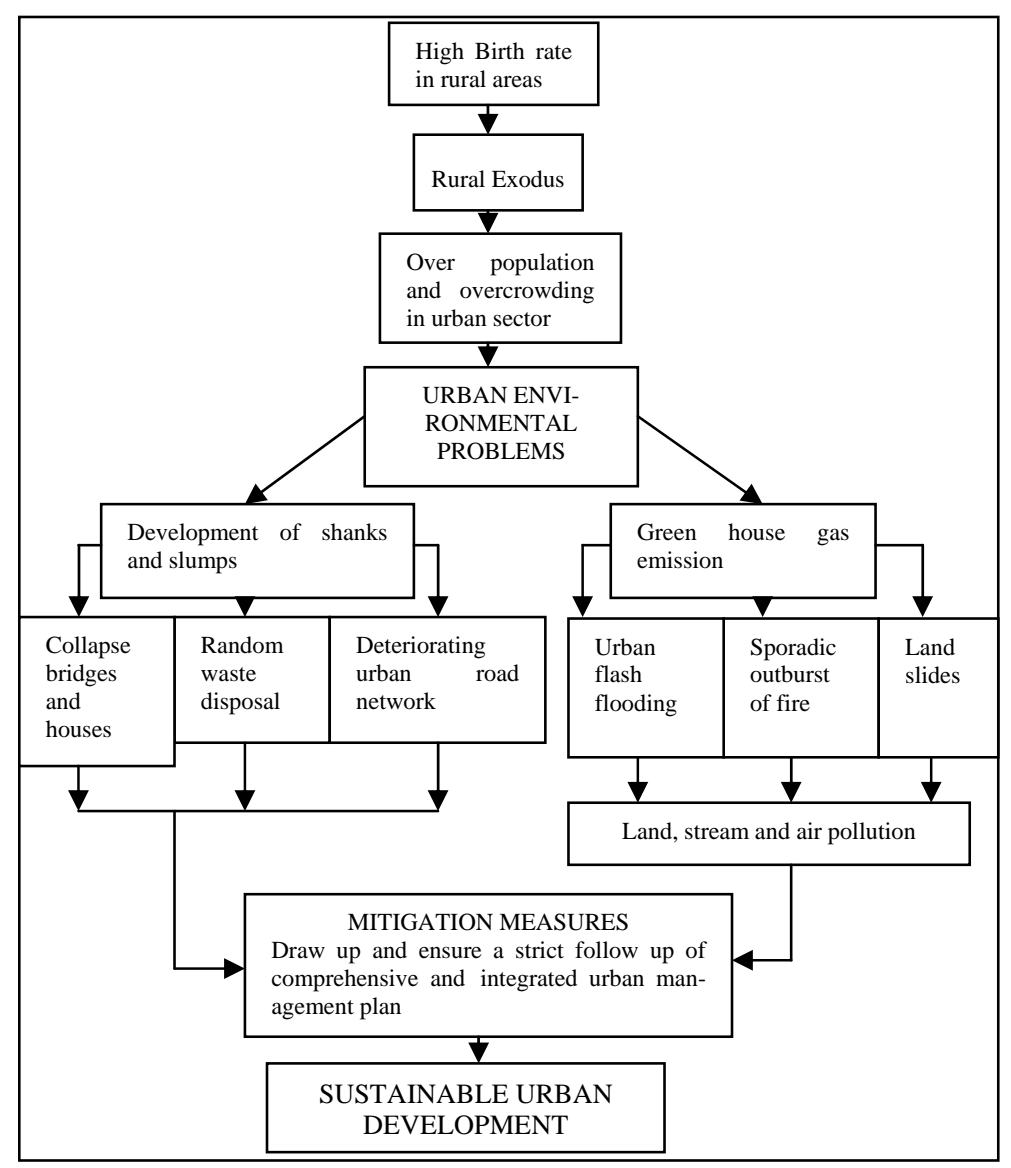

Figure 1. Urbanization and urban environmental problems 
Two interviews were held with the indigenes selected from the aging and young folks. This was recorded on a tape recorder with the prime objective of gathering cross generational perspectives about prevailing environmental problems in Bamenda.

\subsection{Secondary Sources of Data}

Secondary data was gathered through literature review and from data obtained from ministerial delegations operating within the city of Bamenda. Some materials were equally downloaded from the "web of knowledge" data base of Vrije Universiteit Brussels http://www.vub.ac.be/ BIBLIO/ubwebsite_database_alpha_en.html\#W by using key words such as urban environmental problems and causes of urban growth. The Human Ecology library of Vrije Universiteit Brussels was equally used to collect some information from books.

\section{Urban Growth Patterns}

\subsection{Global Pattern}

The 21st century is the Century of the City. Half of the world's population already lives in urban areas and by the middle of this century; most regions of the developing world will be predominantly urban [3]. Cities are perhaps one of humanity's most complex creations, never finished, never definitive. They are like a journey that never ends [3]. Cities drive national economies by creating wealth, enhancing social development and providing employment but they can also be the breeding grounds for poverty, exclusion and environmental degradation.

In some regions of the world, the urban transition occurred decades ago, in the 1950s and 1960s, if not earlier. More than 70 per cent of the populations of Europe, North America and Latin America are already urban; Asia and Africa remain predominately rural, with 40 per cent and 38 per cent of their populations living in urban areas, respectively. However, if current trends continue, half of Africa's population will be urban by 2050. In Asia, the urban transition will occur even earlier, owing to rapid urban growth rates in China, a country that is expected to be more than 70 per cent urban by 2050. Urban growth rates in India will be slower; by 2050, 55 per cent of its population, or 900 million people, will live in cities. Globally, urbanization levels will rise dramatically in the next 40 years to 70 per cent by 2050 .

Every day, 193,107 new city dwellers are added to the world's urban population, which translates to slightly more than two people every second [3]. But not all regions are affected by this growth in the same way or on the same scale. In developed nations, the total increase in urban population per month is 500,000 , compared to 5 million in the developing world. In terms of absolute numbers, the growth of cities in the developing world is ten times that of cities in the global North. Annually, cities in the developing world grew at a rate of 2.5 per cent in the 1990s, compared to an annual growth rate of 0.3 per cent in the developed world [3].

Harmony in cities cannot be achieved if the price of urban living is paid by the environment. Harmony within cities hinges not only on prosperity and its attendant benefits, but on two pillars that make harmony possible: equity and sustainability.

Migration is necessary for the growth and development of nowadays societies, but also detrimental when rural-urban flows exceed the absorptive capacity of towns, leading to a degraded kind of human settlement called "slum",. Urban growth rates are thus highest in the developing world, which absorbs an average of 5 million new urban residents every month and is responsible for 95 per cent of the world's urban population growth [3]. The problems of poverty and deprivation in rural areas and their spill-over into urban areas cannot be solved by preventing urbanization and keeping rural people confined to rural areas-which would be impossible in any event [4].

\subsection{Socio Demographic Characteristic and Spatial Evolution of Bamenda}

Bamenda center already stretched beyond Old Town in the early 1980's. This area also known by the name Ntambag II and III experienced a high population bump as was the case with quarters like Azire, Musang, Mougheb and Bayel. GRA was moderately inhabited. The newly occupied areas were amongst others Ntarikon, Nitop, Atuakom, Ngomgham, Ntambesi and Mendankwe. The development of Bamenda happened very quickly over the last two decades. This growth was in every sense profoundly alters the cityscape. From 1982 to 1992, the spatial evolution was in the low density neighbourhoods inhabited in 1982. Accessibility has also played an important role in extending the city Opening Many secondary roads has encouraged the extension of linear habitat around these roads. Since 1992, the urban area of Bamenda has continued to spread in all directions: the north-west it extends to Alamatu, crossing the north-east to Mulanga and Ntenefor to six Nkwen Mile. Ntatru, Atuakom, high Ngomgham, bayel III, IV and Sisia Abangoh. The area now known GRA extension, with part of Mendankwe now incorporated in the urban space. 
Table 1. Evolution of population - Bamenda

\begin{tabular}{ccc}
\hline Years & Population & Growth rate \\
\hline 1976 & 47.955 & \\
1987 & 110.692 & 7.9 \\
1992 & 148.812 & 6.04 \\
1997 & 199.496 & 4.67 \\
2003 & 249.489 & \\
2005 & 298.300 & Projections \\
2007 & 302749 & \\
\hline
\end{tabular}

Source: Adapted from MINDU Bamenda (2007).

P2007 =P97 (1-r/100) n-1, P2005= Population in 2005, P97= Population in 1997, $\mathrm{n}=$ number of years in between 1997-2007, $\mathrm{r}=$ Population growth rate

\section{The Natural Environment of Bamenda}

The city of Bamenda was chosen for this study because of the peculiarity of its physical environment on the one hand and its susceptibility to natural hazards on the other. The Bamenda station escarpment has an imposing characteristic has transformed the morphology of Bamenda city. Bamenda could be divided into an upper and lower half. The upper half known as Up-station lies at $1455 \mathrm{~m}$ above sea level and is host of the administrative and government residential area (GRA). The lower half of Bamenda lies between 1330m above sea level around Sisia quarter to a height of $1200 \mathrm{~m}$ around Lower Ngomgham quarter. Up-station is separated from down town Bamenda by an abrupt escarpment. This abrupt gradient difference of $255 \mathrm{~m}$ between Up-station and Lower Ngomgham could permit an easy and steady discharge of runoff into river courses under natural conditions should the natural ecology be left undisturbed by human activities.

\section{Results and Discussion}

\subsection{Land Tenure System}

The present state of urban development in Bamenda could best be understood with recur to land administration practices that transcend to colonial days. Most land in sub-Saharan Africa has no registration of who owns it or has rights to use it. Various new initiatives are underway to address this, in the belief that land registration and titling can promote investment, reduce poverty and encourage better natural-resource management [5].

The rapid and unplanned growth of the Bamenda urban space is having huge repercussions on the environment and resource processes in the rural hinterland and on the regional economy in general. Bamenda region provides a good illustration of the impact that urbanization can have on the rural landscape and economy [6].

\subsection{Environmental Problems Emanating from Rapid Urbanization}

\subsubsection{Floods}

Natural hazards in the form of flash floods are very common within Bamenda. Given the increased rate at which surfaces are being paved, new houses constructed and stream channels distorted and reduced in width span, flooding now features top on the list of natural hazards within Bamenda. There are a total of $48.8 \mathrm{~km}$ of tarred primary and secondary roads in Bamenda. In the recent past, floods has taken away scores of souls, damaged roads and buildings and above all other properties of economic value have been reduced to bear zero within the twinkle of an eye.

Although one might argue that from the point of view of earthquake building risk, the system is relatively good, unfortunately it must be noted that there is hardly any building regulation which applies to floods [7]. Inhabitants in certain quarters in Bamenda are beginning to notice failures in their architectural design of their houses.

These areas are built along and across the confluence of a centripetal drainage network that drains all the flood waters generated over the entire city of Bamenda. More than $90 \%$ of respondent living within flood affected area declared that they are always afraid of heavy rains and are very willing to quit their present residence for a new one should the government provide them necessary finance and site for them to relocate. Inhabitants are aware of the dangers that come with their living in such flood prone areas but lack the financial and material means to afford for a new site elsewhere. As a coping strategy to the floods in Bamenda, more than $70 \%$ of inhabitants within these flood areas have resorted to the putting sand in bags to block advancing water during floods, others use buckets to send out water from homes after flooding while the well to do afford to raise their foundations to an appreciable height that "might" not be attained by flood waters. Some of them even declare: "flood has caused a lot of destruction to our properties, making life a living hell in Bamenda". The table below shows some of the losses incurred through urban environmental hazards in Bamenda in the recent past.

There were plans by the Bamenda city authority to rehabilitate and raise the height of bridges along major roads axis that are prone to flooding after heavy rains. As if to make things worse, bridges constructed are just a miniature and are still unable handle huge volumes of water after heavy rains. The reasons to this dilemma could be twofold: misappropriation of funds allocated for engineering projects by unscrupulous contractors or an increase tendency of the population to deposit waste into river courses resulting in heavy river load after rains. 
Table 2. Impact of environmental hazards emanating from rapid urbanisation: Bamenda

\begin{tabular}{|c|c|c|}
\hline \multicolumn{3}{|c|}{ Landslide and mud flow } \\
\hline Quarters & Damages & Year \\
\hline Up-Station & $\begin{array}{l}\text { Traffic arrest on major high way } \\
\text { for about } 24 \text { hours }\end{array}$ & $4^{\text {th }} / 08 / 2009$ \\
\hline Sisia & One death, two seriously injured & $4^{\text {th }} / 08 / 2009$ \\
\hline Abangoh & Three deaths & 2007 \\
\hline \multicolumn{3}{|c|}{ Subsidence } \\
\hline Anindoh & $\begin{array}{l}\text { Collapse of bridge on major nation } \\
\text { highway }\end{array}$ & $7^{\text {th }} / 08 / 2009$ \\
\hline \multicolumn{3}{|c|}{ Floods } \\
\hline Mulang & Two death & 2006 \\
\hline Ngomgham & Houses and properties & Annual \\
\hline Nitop I & Houses and properties & Annual \\
\hline $\begin{array}{l}\text { Ntamulung, } \\
\text { II and III }\end{array}$ & Houses and properties & Annual \\
\hline Ntaturu & One death & 2007 \\
\hline Mougheb & $\begin{array}{l}\text { Swept away } 700 \text { bags of } 50 \mathrm{~kg} \text { ric } \\
\text { One death }\end{array}$ & 2007 \\
\hline Azire & Houses and properties & Annual \\
\hline
\end{tabular}

Source: Field data, 2009

As a consequence of the above, bridges still under rehabilitation are already proving their incapacity to be able to retain the vast volume of water generated from paved surface and roof of buildings after heavy rains.

\subsubsection{Subsidence/Collapse of Bridges}

Subsidence is very common within quarters like Atuazire. Since 2004, most residents of Atuazire have noticed a progressive up serge of water in the form of spring from underneath their foundations. It has now done on this group of people that the onetime stable pond ecosystem whose bed was filled with soil and rocks of varied texture and resistance could pose as potential hazards during present day more than it was about 20 years ago when this area began noticing a progressive encroachment man and his construction works on this ecologically fragile environment. During a field survey and interview session the researcher could notice tilted imposing cracked walls. Many a building have been brought down as a result of the inability of the underlying clay and cretaceous soil materials that once was under pond conditions to resist huge masses of blocks pilled to appreciable heights.

It has been estimated from field survey that if something is not done and done fast, the number of houses that shall continue to suffer from subsidence within AtuAzire quarter shall keep increasing with increase rainfall and wetness of the basement rocks.

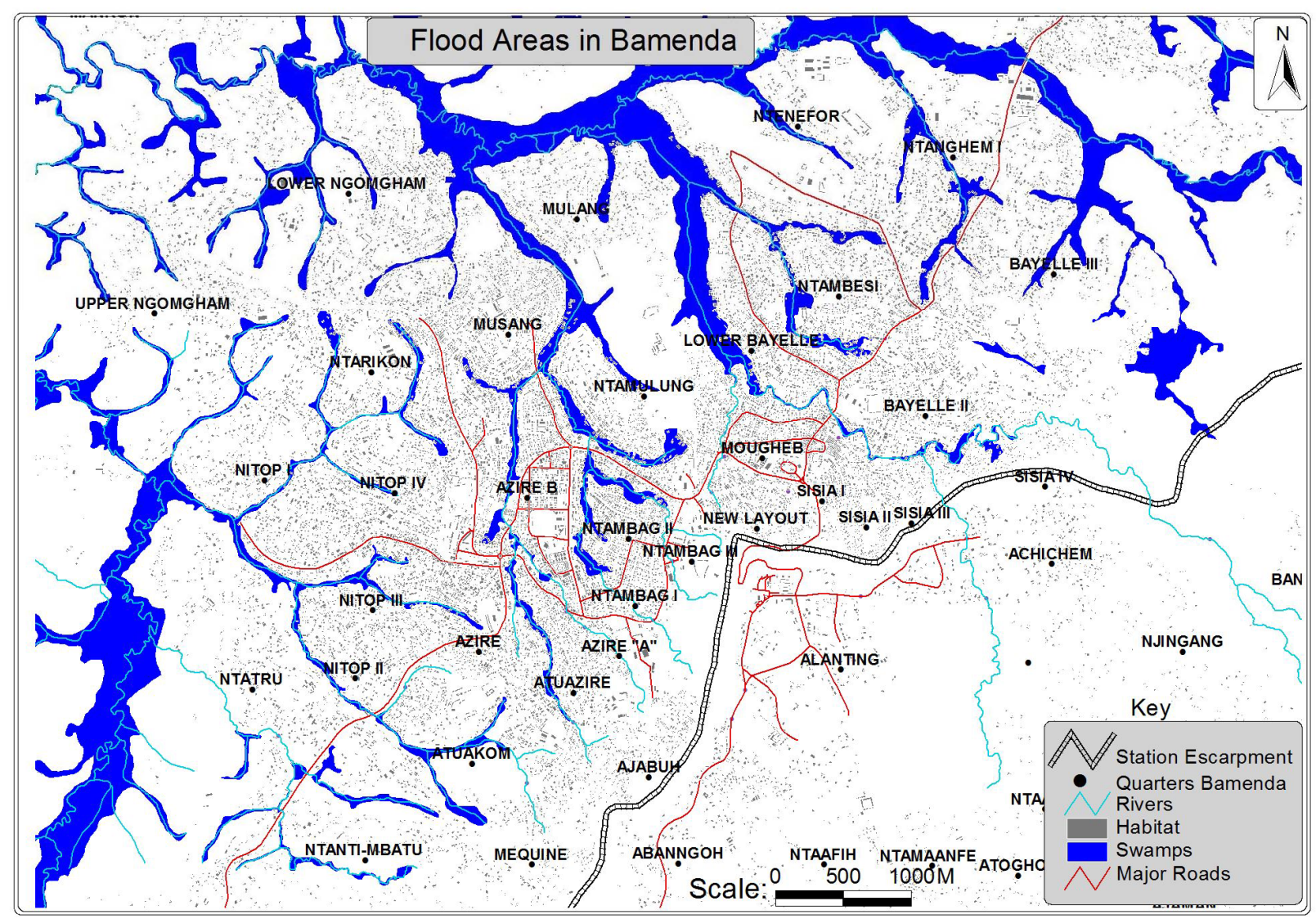

Figure 2. Floods areas in Bamenda 


\subsubsection{Landslides}

Landslide is fast becoming one of the major environmental problems in Bamenda that come about as a result of the rapid urbanization. Landslide is seen to occur in the heart of the rainy season i.e. between the months of July and September with rainfall varying between $340 \mathrm{~mm}$ and $450 \mathrm{~mm}$. Landslide in Bamenda is thus provoked by rapid urban development resulting from progressive occupancy of steeper slopes adapted by cutting terrace-like areas and re-distributing materials in order to provide building sites. Heavy rains have the tendency to soak and dislodge large rock masses sometimes resulting in the complete crushing or burial of an entire housing unit.

Mean values were used to represent the results obtained from the questionnaires that were administered to twenty randomly selected respondents in each of the quarters sampled. Respondent identified landslide and land subsidence to be more common in Abangoh and Sisia quarters while flooding was seen to be more common with New Layout Nkwen, Ngohmgham and Mulang quarters (Figure 3). In the same vein, fire disaster was identified as an emerging urban hazard in Bamenda with its occurrence more rampant during the dry season periods.

\subsubsection{Fire Disaster}

Sporadic outbreak of fire especially during the dry season is fast gaining grounds to becoming a very serious environmental problem emanating from rapid urbanization. Statistics from the army rescue unit indicated that the number of fire outbreaks per year has passed from 10 in 2006 to 59 in 2008 (Table 3 below).

The Kyoto Protocol, the international climate change agreement finalized in Marrakech in 2001 lists six greenhouse gases (or groups of gases) whose emissions signatories to the Protocol agree to reduce. These gases include: Carbon dioxide $\left(\mathrm{CO}_{2}\right)$, Methane $\left(\mathrm{CH}_{4}\right)$, Nitrous

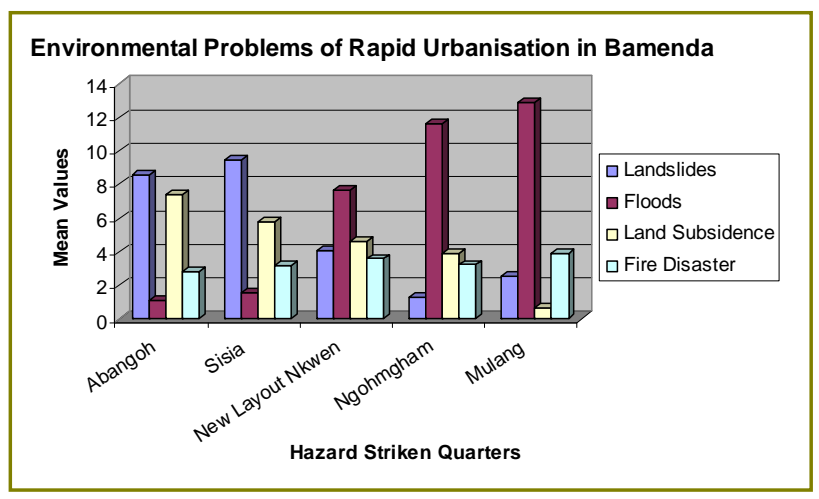

Source: Field data

Figure 3. Urban natural hazards - Bamenda
Table 3. Fire disaster and other urbanization problems

\begin{tabular}{lccc}
\hline \multirow{2}{*}{ Activity } & \multicolumn{3}{c}{ Years } \\
\cline { 2 - 4 } & 2006 & 2007 & 2008 \\
\hline False calls & 4 & 14 & 12 \\
Fire & 10 & 34 & 59 \\
Relief victims & 24 & 51 & 114 \\
Traffic accidents & 2 & 15 & 19 \\
Assistance to people & 4 & 13 & 14 \\
Water, gas, and electricity & 0 & 1 & 0 \\
Protection of property & 0 & 0 & 3 \\
Drowning & 2 & 4 & 3 \\
\hline
\end{tabular}

Source: Army rescue unit - Bamenda.

Oxide $\left(\mathrm{N}_{2} \mathrm{O}\right)$, Fluorocarbons (including hydro fluorocarbons (HFCs) and perfluorocarbons (PFCs)), Sulfur hexafluoride $\left(\mathbf{S F}_{\mathbf{6}}\right)$.

Many of these gases come from natural sources. When fire out breaks thus occurs, there is the release of an appreciable quantity of green house gases into the atmosphere further compounding the phenomenon of climate change which is already being felt within and around Bamenda. $\mathrm{CO}_{2}$ and other green house gases such as methane and $\mathrm{N}_{2} \mathrm{O}$ are released in vast proportions during such incidence.

\subsection{The Mystery behind Natural Hazards}

The natural environment of Bamenda has been overstressed as a result of high population pressure on land. Environmental hazards provoked by rapid urbanization don't show signs of warning before their outburst. They are all too sudden and their impact on the inhabitants living within and without its area of occurrence cannot be underestimated. The first few days of the month of August i.e. $4^{\text {th }}-10^{\text {th }}$ August 2009 were characterized by sporadic outburst of natural environmental hazards within the city of Bamenda. Environmental experts will be quick to say Bamenda had exceeded its carrying capacity. Geologists and Geographers will definitely have their own site of the story: there has been the percolation and progressive upwelling of soil top layer due to water accumulation from heavy rains.

Given the uncertainty that looms, we must not forget the fact that the indigenes have their own part of the story. To this effect therefore:

- Major road in the heart of the city linking the Central.

- Business District (CBD) to the administrative centre was attacked by landslide (4 ${ }^{\text {th }}$ August 2009, Figure 4), few day later and about $4 \mathrm{~km}$ away from the landslide area, Major bridge linking the North West region to the rest of the country collapsed, $7^{\text {th }}$ 
August 2009.

- Within the same days, at the foot of the Bamenda station escarpment, a major landslide occurred killing a child and completely engulfing a housing unit into its bosom.

- As if that were not enough, some major incidence of flooding and destruction of properties were reported in many parts of the city.

The bridge collapse and landslide along the major road axis brought untold suffering to people travelling into and out of the city of Bamenda. This saw the transportation of corpses over and across the natural barriers by porters, people trekked in mud, commercial and private vehicles were grounded because of lack of fuel supply and above all people missed their appointments. These natural environmental hazards drew the attention of both national and international press organs. It then began to done on the people of Bamenda that "the God's have forgotten them”.

Indigenous people put the blame on engineers for failing to respect and apiece the "Gods" of the land before and after major construction works. In the construction of the backward retaining wall, two anonymous indigenes recounted:

\section{Anonymous indigene aged 29 years:}

"Look at that forest over there. That is where the "God's" of this quarter reside. The time has come for the engineers who constructed this backward retaining wall (Figure 7) to know that our God is not someone you can joke with and go scotch free. Before the engineers could begin working on that site we advised them to bring some money and drinks and food for our Gods to be apiece. They hesitated now look at what this is costing them and the government. To site you an example, that this black forest is not a forest to joke with. Some few years back, I was doing laundry in this same stream that has swept away the bridge. I suddenly noticed a sound in the forest. It appeared as if there was something in the forest moving slowly but steadily towards my direction. Little did I know what was happening? I suddenly saw a huge volume of water rushing towards me. That was floods waters from coming from no where since there were no signs of rains around Bamenda on that faithful day. So I think it's high time these engineers involved the local community in the planning of their projects".

Anonymous indigene aged 71 years:
"I was born in this town and have lived here all my
live. The magnitude of the environmental hazards
that have occurred during the past couple of days
in this city hasn't been equaled by any since I was
born. Perhaps it could be because of the high
population in this city these days. But all the same
we must not forget the fact that the "Gods" of the
land need to alwavs be abiece"

If one were to go by the fact that the frequency of environmental hazards in present day Bamenda is on an increase and hasn't been equaled by any in the history of Bamenda, and also by the fact that the population of Bamenda has increased from 110.692 people in 1987 to a projected high of 302749 people by 2007, then one might be tempted to believe that rapid urbanization stimulates the occurrence of environmental hazards. With this in mind therefore the null hypothesis is accepted.

\section{Sustainable Cities: Meeting the Millennium Development Goal}

The lack of improved sanitation and water facilities are two of the four defining characteristics of urban slums. The others are durable housing and sufficient living area. In 2005, slightly more than one third of the urban population in developing regions lived in slum conditions; in sub-Saharan Africa, the proportion was over 60 per cent [8]. It is particularly ironic that the battle to save the world's remaining healthy ecosystems will be won or lost not in tropical forests or coral reefs that are threatened but on the streets of the most unnatural landscapes on the planet [9]. In today's risk adverse society, communities are expected to identify geo-hazards that affect their existing and planned developments and infrastructure and prepare zoning maps based on these geo-hazards, as part of their infrastructure risk management and emergency response planning [10].

Simple, low-cost interventions to correct these specific

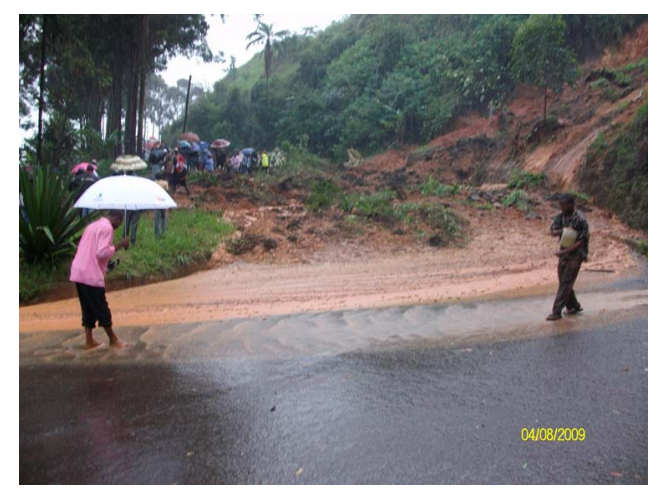

Source: Field data 2009

Figure 4. Landslide on the Bamenda station escarpment 
deficiencies would go a long way towards improving the lives of many slums dwellers.

\section{Recommendation}

Culshaw [11] calls for an enhanced understanding of ground conditions to better define hazard zoning in urban environments, linking hazard, infrastructure and risk, and an improved recognition where mitigation is required. The following key point need to be taken into consideration when drawing up urban management plans in an effort to eradicate the environmental consequences of urbanization in a third world city like Bamenda.

- Develop building and population risk zonation.

- This building risk map from the point of view of reduction, the building risk map highlights the areas where building re-strengthening or demolition works are necessary.

- A system that combines economic incentives (e.g. Lower construction permit fees or annual property taxes) to develop medium-rise housing using particular structural systems together with educational campaigns.

- Government institutions should ensure that the population understands that they are both victims and contributors of environmental problems.

- Architects, urban planners and engineers need to cooperate in order to develop projects that not only fulfill its objectives in terms of flood levels [12] reduction but also consider other needs of local communities and the urban poor.

- Since urban flash flooding is one of the most pressing environmental problems in Bamenda, canals and bridges should be constructed with widening ends and not with tapering ends. Such is an application of urban geomorphology and hydrology to city engineering practice.

The use of distributed storage and on-site control techniques are usually cheaper than traditional approaches of enlargement of the drainage net [13]. In this way, developing countries, where significant investment capability restrictions is a reality, should make an effort to use these kind of solutions more frequently in post-event engineering constructions. One of the proposed actions consists in the possibility of re-urbanization of public squares to work as temporary detention reservoirs. Maps therefore seem to be the chosen interface for transferring information from geomorphologists to engineers and planners [13].

A combination of indigenous approaches to hazard management and technical appraisal by engineers is therefore necessary in the analysis and mitigation of hazards within Bamenda. There is need for a multidisciplinary research and action into the current problems of Bamenda.

\section{Conclusions}

At the confluence of high birth rate and unplanned/rapid urban development lie the devastating consequences of urban environmental hazards. Such hazards have been seen to be on an increase and the degree and losses both of life and property increase with increase in the proportion of the rural poor who flood the town each day in quest for a better living. There is need for a change of mentality of the Bamenda man towards an awareness that the environment has its carrying capacity and when over stretched could lead devastating respond in an undesirable manner. The time to re-planning and reshaping the urban spatial structures of Bamenda is now if this city is to evade greater catastrophe in the pipeline.

\section{REFERENCES}

[1] C. Abbott, "Urbanization,” Dictionary of American History, The Gale Group Inc., 2003. Encyclopedia.com: http://www.encyclopedia.com/doc/1G2-3401804367.html

[2] Agenda 21, United Nations Conference on Environment \& Development Rio de Janerio, Brazil, 1992.

[3] UN Habitat, State of the World's cities, Harmonious Cities, pp. 1-280, 2008/2009.

[4] UNESCO, "Education for sustainability, from Rio to Johannesburg: Lessons learnt from a decade of commitment," World Summit on Sustainable Development Johannesburg, pp. 1-46, 26 August-4 September 2002.

[5] C. Toulmin, "Securing land and property rights in Sub-Saharan Africa: The role of local institutions," International Institute for Environment \& Development (IIED), London, UK. Journal of Land Use Policy, Vol. 26, No. 1, pp. 10-19, 2008.

[6] Acho-Chi, "Human interference and environmental instability: Addressing the environmental consequences of rapid urban growth in Bamenda, Cameroon,” Journal of Environment and Urbanization, Vol. 10, pp. 161-174, 1998.

[7] L. Motoyana and I. Masserb, "Management of natural hazard risk in Cartago, Costa Rica,” Habitat International, Vol. 29, pp. 493-509, 2005.

[8] UN Millennium Development Goal Report, pp. 1-54, 2008.

[9] World watch Institute, "Preface," State of the World 2007: Our Urban Future, New York and London: W. W. Norton and Company, pp. 24, 2007.

[10] H. Lan, C. Martin, C. Froese, T. Kim, A. Morgan, and D. Chao, "A web-based GIS for managing and assessing landslide data for the town of Peace River," Canada Natural Hazards and Earth System Sciences, Vol. 9, pp. 1433-1443, 2009.

[11] M. G. Culshaw, "The seventh glossop lecture from concept towards reality: Developing the attributed 3-D geological model of the shallow subsurface,” Journal of Engineering Geology and Hydrogeology, Vol. 38, pp. 231284, 2005.

[12] C. Flávio, et al., "Comparison of different multifunctional landscapes approaches for flood control in developing countries,” Computational Hydraulic Laboratory Federal University of Rio de Janeiro, Session 1.2, pp. 83-90, 2007.

[13] G. Avijit and R. Ahmad, "Geomorphology and the urban tropics: Building an interface between research and usage,” Journal of Geomorphology, Vol. 31, pp. 133-149, 1999. 